DOI: https://doi.org/10.24127/ajpm.v10i3.4034

\title{
STUDENT DIFFICULTIES IN SOLVING MATHEMATICS QUESTIONS BASED ON MATHEMATICAL LOGIC INTELLIGENCE DURING THE COVID-19 PANDEMIC
}

\author{
Vera Dewi Susanti $^{1^{*}}$, Rika Wulandari ${ }^{2}$ \\ ${ }^{1 *}$ Universitas PGRI Madiun, Madiun, Indonesia \\ ${ }^{2}$ Universitas Trunojoyo Madura, Madura, Indonesia \\ *Corresponding author. \\ E-mail: $\quad$ vera.mathedu@unipma.ac.id ${ }^{1 *}$ \\ rika.wulandari@trunojoyo.ac.id ${ }^{2)}$
}

Received 22 July 2021; Received in revised form 12 September 2021; Accepted 17 September 2021

\begin{abstract}
This study aims to analyze students' difficulties in solving mathematical problems based on mathematical logic intelligence. The population of this research is the fourth-semester students of Mathematics Education, Universitas PGRI Madiun, totaling 52. While the subjects of this research are 3 students based on mathematical logic intelligence. The subject is taken by one student each from high, medium, and low mathematical logic intelligence. This research is descriptive qualitative research using the triangulation technique. Data collection techniques used are tests, interviews, and documentation. Instruments in the form of advanced mathematical material tests and tests of mathematical logic intelligence. The data analysis technique uses data reduction, data presentation, and conclusion drawing. The conclusion in this study is that subjects who have high mathematical logic intelligence have no difficulty in working on problems, subjects of mathematical logic intelligence are having difficulty at the stage of re-examining their answers, and subjects of low mathematical logic intelligence have difficulty in solving problems properly and have not been able to re-examine the answers.
\end{abstract}

Keywords: Difficulty analysis; mathematical logical intelligence; advanced mathematics.

\begin{abstract}
Abstrak
Penelitian ini bertujuan untuk menganalisis kesulitan mahasiswa dalam menyelesaikan soal matematika berdasarkan kecerdasan logika matematika. Populasi penelitian ini mahasiswa semester IV Pendidikan Matematika Universitas PGRI Madiun yang berjumlah 52. Sedangkan subjek penelitian ini adalah 3 mahasiswa berdasarkan kecerdasan logika matematika. Subjek tersebut diambil masing-masing satu mahasiswa dari kecerdasan logika matematika tinggi, sedang dan rendah. Penelitian ini merupakan penelitian kualitatif deskriptif dengan menggunakan triangulasi teknik. Teknik pengumpulan data yang digunakan adalah tes, wawancara dan dokumentasi. Instrumen berupa tes materi matematika lanjut dan tes kecerdasan logika matematika. Teknik analisis data menggunakan reduksi data, penyajian data, penarikan kesimpulan. Kesimpulan pada penelitian ini adalah subjek yang memiliki kecerdasan logika matematika tinggi tidak mengalami kesulitan dalam mengerjakan soal, subjek kecerdasan logika matematika sedang kesulitan pada tahap memeriksa kembali jawabannya dan subjek kecerdasan logika matematika rendah kesulitan dalam menyelesaikan soal dengan baik dan belum mampu memeriksa kembali jawabannya.
\end{abstract}

Kata kunci: Analisis kesulitan; kecerdasan logika matematika; matematika lanjut.

This is an open access article under the Creative Commons Attribution 4.0 International License

\section{INTRODUCTION}

On January 30, 2020, WHO declared it a global health emergency
(Cucinotta \& Vanelli, 2020; LloydSherlock et al., 2020; Mahase, 2020; Sohrabi et al., 2020; Watkins, 2020). 
Countries that have contracted COVID 19 and experienced many deaths have reached more than 200 countries (Lin et al., 2020; Shereen et al., 2020; Wahyono et al., 2020; Worldometers, 2020). This is a very big health threat for people in the world. One of the countries that have a vulnerable health system is the Republic of Indonesia (Sohrabi et al., 2020). This affects policy changes and reforms to be implemented including the education sector (Anderson, 2020; Azzi-Huck \& Shmis, 2020; Cucinotta \& Vanelli, 2020; Horn, 2020; Huang et al., 2020; OSPI, 2020; Sohrabi et al., 2020; US Department of Health and Enviromental Control, 2019; Zhang et al., 2020).

Policies in the world of education change learning that has to come to class or a building, in this case, the campus, to just stay at home. The government's recommendation to stay at home and physical and social distancing must be followed by changing the faceto-face learning mode to online (Aderholt, 2020; Karp, P., \& McGowan, 2020; UNESCO, 2020). One way that the government has taken to prevent its spread is through a circular letter from the Ministry of Education and Culture of the Directorate of Higher Education No. 1 of 2020 regarding the prevention of the spread of Corona Virus Disease (Covid-19) in universities.

One of the universities that follow these regulations is Universitas PGRI Madiun. Since April 2020, this campus has started implementing Study from Home to replace face-to-face lectures in class. The implementation of the SFH requires lecturers at Universitas PGRI Madiun to carry out online learning as an alternative to face-to-face lectures. Even though it is carried out online, learning must still be able to increase student interest in following it. E- learning is the use of information and communication technology in the teaching and learning process (Hasan, 2020; Muthuchamy, I., \& Thiyagu, 2011; Rosenberg \& Foshay, 2002; Setiaji \& Dinata, 2020; Setiawan et al., 2019; Setyoningsih, 2015). E-learning is one of the newest learning models in the world of education that is able to overcome the limitations of space which have been the weakness of conventional learning models (Hasan, 2020).

There are so many e-learning platforms that can be accessed by both lecturers and students. SEVIMA Edlink, Moodle, Edmodo, Schoology, Google Classroom are examples of e-learning platforms that provide LMS (Learning Management System) facilities. LMS is a system that provides information and communication technology-based classes that can be filled by lecturers with materials, assignments, learning resources, and others (Abu Shawar \& Al-Sadi, 2010). This system also facilitates communication between lecturers and students. In addition, there is also Zoom, Google Meet, Skype which can be used for video conferencing.

Universitas PGRI Madiun has its own e-learning with the name UNIPMA e-learning. Unipma's e-learning also provides LMS facilities. In this facility, lecturers can hold meetings via zoom, can provide material in the form of videos and PPT, discuss directly either individually or in groups, give assignments, and several other facilities. In general, e-learning has benefits, including: (1) easy preparation, lecturers can easily share class codes, (2) effective time, lecturers can quickly create, check and assess student assignments without paper, (3) better organization, students can be more organized in organizing assignments 
and materials, (4) Good communication, with discussion forums lecturers and students can easily make announcements or ask questions (Alqahtani \& Rajkhan, 2020; Amelia, Hasanah, 2020; Hariani \& Wastuti, 2020; Irfan et al., 2020). UNIPMA's Elearning also has the same benefits.

Although broadly speaking, UNIPMA's e-learning can provide many benefits and can overcome learning during a pandemic (Krisdiana, I., Murtafiah, W., Masfingatin, T., Setyansyah, R. K., \& Susanti, 2021). However, the learning outcomes through UNIPMA's e-learning are not optimal. This can be seen from the value of students who are still below a score of 60. This low score indicates difficulties in working on the questions. For this reason, it is necessary to investigate the difficulties of students in using facts, skills, understanding concepts, and applying principles in solving math problems.

According to Fadhli (Fadhli, 2015), a student's learning difficulties usually evident from the decline in academic performance or a learning achievement. The low level of success in learning mathematics is due to There are several reasons, including the difficulty factor of students in receiving the material in mathematics, and other factors caused by students' inability to solve mathematical problems (Sholekah et al., 2017). Furthermore, a person is said to understand mathematics if he is able to explain mathematical concepts and facts in a simple form and is able to connect them logically between different facts and concepts (Dowker, 2004). Several studies have stated that the causes of students' mathematical difficulties are due to arithmetic errors, incorrect procedures, counting, and reading skills (Bzufka et al., 2000; Kelanang \& \& Zakaria, 2012).

In another study, it was stated that there are two kinds of difficulties related to inequalities, namely arithmetic difficulties and lack of meaning and the effect of mathematical symbolization on students' performance in translating problems in making mathematical equations (Blanco \& Garrote, 2007). Dwidarti's research (Dwidarti et al., 2019) shows that subjects with high and moderate mathematical abilities still have difficulty in applying principles and skills, while subjects with low mathematical abilities still have difficulty understanding concepts, applying principles, and skills. In this study, although the subject had high mathematical ability, he still had difficulty in applying mathematical principles and skills. It is necessary to further investigate whether students with mathematical logic abilities will give the same results or not on advanced mathematics material. Moreover, this research was analyzed when students did online learning.

Advanced Mathematical Studies is a course given in the semester. In this course, broadly speaking, the material studied is not far from high school / vocational / MA material such as circular equations, linear programs, limits, geometric transformations, etc. Although it has been studied before, there are still many students who have difficulty in solving these problems. This is also influenced by the school background of previous students who came from vocational schools where not all Mathematics subject matter was given. So that from different backgrounds it also shows that the level of intelligence in mathematical logic is also different. 
Lwin (Lwin, 2008) explains that, logical-mathematical intelligence is "the ability to handle numbers and calculations, patterns, and logical and scientific thinking". Someone who has logical-mathematical intelligence will be able to make classifications of information, compare information and strategies to solve problems correctly, process numbers, and use inductive and deductive thinking in solving problems. In previous research which revealed that logical-mathematical intelligence has main components, namely mathematical calculations, logical thinking and reasoning, inductive and deductive reasoning, sharpness of patterns and relationships, as well as forming hypotheses and re-checking the hypotheses that have been made (Mujiani, 2016; Mukarromah, 2019; Willis \& Johnson, 2001). Yaumi states that someone who can solve problems easily means that person has logicalmathematical intelligence. Thus, logical-mathematical intelligence can be used by students in solving mathematical problems so that the objectives of learning mathematics can be achieved optimally (Yaumi, 2012).

Researchers have conducted research related to mathematical logic intelligence, this study analyzes students' adaptive abilities in terms of mathematical logic. In this study, the researcher also investigated mathematical logic, but the analysis carried out was to analyze student difficulties in terms of mathematical logic. Analysis of this difficulty, the researcher intends to analyze students' difficulties in solving math problems based on mathematical logic intelligence when learning is carried out through UNIPMA e-learning.

\section{METHOD}

This research was conducted at the Universitas PGRI Madiun. The research subjects were students of the fourth semester of mathematics education who took the Advanced Mathematics Studies course. The study was conducted in the even semester during the Study from Home period due to the COVID-19 pandemic. The online application used in this course is UNIPMA e-learning.

This research is descriptive qualitative research. It is research that aims to describe the phenomena that occur in the research subject in depth. In this study, the phenomena observed and will be described are the difficulties faced by students in solving Advanced Mathema-tics Studies questions when participa-ting in learning through UNIPMA E-Learning.

The population in this study were students in the fourth semester of Mathematics Education, Universitas PGRI Madiun, totaling 52 students. Of the 52 students were given a logicalmathematical intelligence test to get one student each based on mathematical logic intelligence which is then used as a research subject. The logicalmathematical intelligence grouping is based on the Table 1 (Suharsimi, 2012).

Table 1. Logical-mathematical intelligence grouping

\begin{tabular}{lcc}
\hline No & Description & Category \\
\hline 1 & $s>\bar{x}+S D$ & High \\
2 & $\bar{x}-S D \leq s \leq \bar{x}+S D$ & Medium \\
3 & $s<\bar{x}-S D$ & Low \\
\hline
\end{tabular}

The instruments in this study were questions of advanced mathematics learning in the form of essays and multiple-choice mathematical logic intelligence tests. 
DOI: https://doi.org/10.24127/ajpm.v10i3.4034

The validity of the data in this study using triangulation techniques. Triangulation is a technique used to test the credibility of data by checking data on the same source with different techniques (Sugiyono, 2012). The data that has been obtained from the test technique is checked again with interviews to ensure the data obtained are truly valid. The data analysis technique uses data reduction, data display, concluding drawing (Sugiyono, 2012).

\section{RESULT AND DISCUSSION}

Based on the grouping of mathematical logic ability test scores, the following data were obtained.

Table 2. Logical-mathematical intelligence grouping

\begin{tabular}{ccc}
\hline No & Description & Category \\
\hline 1 & $s>68,2$ & High \\
2 & $47,2 \leq s \leq 68,2$ & Medium \\
3 & $s<47,2$ & Low \\
\hline
\end{tabular}

From Table 3, 3 students were selected consisting of 1 student with high logical-mathematical intelligence, 1 student with medium logicmathematical intelligence, and 1 student with low logic-mathematical intelligence. The data on the logicalmathematical intelligence test scores of the 3 students can be seen in Table 3 .

Table 3. Logical-mathematical intelligence data

\begin{tabular}{lcc}
\hline Name & $\begin{array}{c}\text { Category Logical } \\
\text { Mathematical Ability }\end{array}$ & Score \\
\hline YEP & High & 83 \\
MPW & Medium & 67 \\
AS & Low & 44 \\
\hline
\end{tabular}

From the answers of each subject, the YEP subject was able to state the information that was known and asked correctly. This subject used all the information to solve the problem. The subject can estimate the method that will be used to solve the problem. Subject YEP can use his knowledge of geometric transformations, trigonoccmetric formulas, matrix operations to solve problems. YEP also re-examined the answers it had. Based on the interview YEP can also explain information from the questions, can explain the steps to solve the problem, explain the calculation of the answer and can reexamine the answers obtained.

The results of tests and interviews on YEP subjects, there were no difficulties in solving advanced mathematics problems. YEP, subjects can explain the information contained in the questions, can explain the steps in solving the questions, and can solve the questions according to the steps and produce the correct answers, and can reexamine the answers. As a subject who has high logical-mathematical intelligence, YEP sees and observes patterns and relationships between data. YEP solves mathematical problems, plays problem-solving strategies. This subject tends to use a variety of graphics both to please themselves (as a hobby) and to convey information to others. Students with high mathematical intelligence have good and systematic thinking, reasoning, and solving abilities (Kobandaha \& Fuad, 2019; Rahbarnia et al., 2014).

MPW students can state the information that is known and asked correctly. The subject MPW is not able to predict the method that will be used to solve the problem. MPW subjects can use their knowledge to solve problems. MPW subjects are also able to use their knowledge of geometric transformations. The MPW subject was unable to re-examine the conjecture that had been made. This can be seen in the MPW answer in the following Figure 1: 


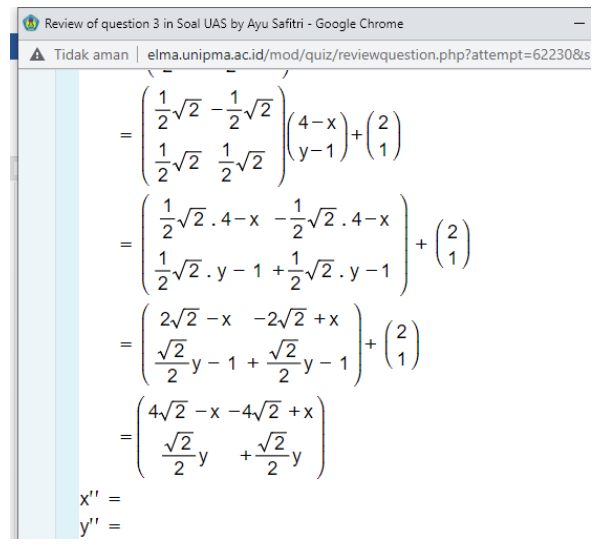

Figure 1. MPW answer results

Based on the Figure 1, MPW can only solve problems. MPW has not rechecked the answer whether it is correct or not. Based on interviews, MPW can explain the information on the questions, can explain the steps for solving the questions even though the answer sheets are not written, can solve the questions well. But still confused to check again whether the answer is correct or not.

AS subjects can state some of the information that is known and asked correctly. AS subjects can use their knowledge of geometric and trigonometric transformations and to solve problems. AS subjects have not been able to use their knowledge of matrix multiplication to solve problems. This can be seen in the AS answer in the Figure 2.

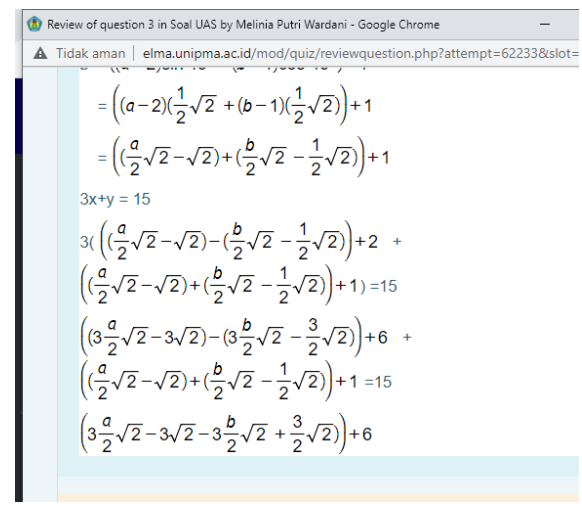

Figure 2. AS answer results
From the AS, it can be seen that the AS subject was wrong in calculating the matrix multiplication. From this answer, the error that AS made was multiplying row 1 column 2 in the first matrix with row 1 column 1 in the second matrix, and row 2 column 1 with row 1 column 1 in the second matrix. What AS should do is multiply row 1 column 1 in the first matrix by the first row of the first column in the second matrix and multiply the second row of the first column in the first matrix with the first row of the second column Likewise row 2 in the first matrix with the first column in the second matrix. So that the AS answer is generated in the red box as shown in Figure 2. Because the AS was wrong in the middle of the calculation to solve the problem so the AS did not give the correct answer. In addition, from the results of the AS answer also did not recheck the answer. Based on the interview, AS can explain the information that is known from the problem, can explain the steps for solving the problem, but in its application it has not been able to solve the problem properly because the AS does not master the matrix material. In addition, the AS has not been able to re-examine the answer.

From the results of tests and interviews on YEP subjects, there were no difficulties in solving Advanced Mathematics Studies. YEP subjects can explain the information contained in the questions, can explain the steps in solving the questions, and can solve the questions according to the steps and produce the correct answers, and can reexamine the answers. As a subject who has high logical mathematical intelligence, YEP sees and observes patterns and relationships between data. YEP solves mathematical problems, plays 
problem solving strategies. This subject tends to use a variety of graphics both to please themselves (as a hobby) and to convey information to others. Students with high mathematical intelligence have good and systematic thinking, reasoning, and solving abilities (Kobandaha \& Fuad, 2019; Rahbarnia et al., 2014). The concepts in mathematics carried out by YEP are systematic, logical, and arranged from simple to complex, the understanding gained is also based on previous knowledge (Mustikawati, 2020).

From the results of tests and interviews, MPW subjects were able to correctly state the information that was known and asked. The subject can explain the method that will be used to solve the problem. MPW subjects can use their knowledge to solve this problem. However, MPW subjects had difficulty re-checking their answers. As a subject who has medium logicalmathematical intelligence, MPW has difficulty in re-checking the answer whether it is correct or not. This is in line with previous research which says that a person is said to understand mathematics if he can explain mathematical concepts and facts in a simple form and can connect them logically between different facts and concepts (Alfeld, 2004; Dowker, 2004). In this case, students with medium mathematical logic intelligence can explain and connect logically between planning and mathematical concepts but have not been able to prove the truth.

The results of this study are also by research conducted by Farah Faizah which says that high logicalmathematical intelligence can understand problems well, determine the strategies used in solving problems, determine results that are by the problem, can carry out examinations of their work and perform calculations related to the additional problems given (Faizah, F., Sujadi, I., Setiawan, 2017).

From the results of tests and interviews, AS subjects able to explain information that is known from the problem, able to explain the steps for solving the problem. However, in its application, AS subjects have difficulty in solving problems well because AS does not master the matrix material. In addition, the US has not been able to reexamine the answer. As a subject who has low logical mathematical intelligence, the AS who has difficulty in learning mathematics generally lies in the lack of understanding of concepts and principles in mathematics (Abdurrahman, 2012; Huda, N., \& Kencana, 2013; Sudirman et al., 2018). Ulya also said that the ability to solve mathematical problems is still low, so the planning of mathematics learning needs to be reviewed by the teacher so that it can produce maximum student problem solving abilities (Ulya, 2015). In this case, subjects with low mathematical logical abilities may not be able to solve problems because the learning process or lectures used are not suitable (Susanti, 2018).

From the results of Sastyawati's research, it is stated that students who have low logical-mathematical intelligence, where the ability to think logically, mathematical calculations, and algebraic operations are lacking, causes in answering structured questions, do not understand and are confused about the meaning of the question (Sastyawati, 2012) This can also be seen from the work of AS subjects, namely the subject has not been able to find a form of solving the problem and has not produced the right answer. 
DOI: https://doi.org/10.24127/ajpm.v10i3.4034

\section{CONCLUSIONS AND SUGGESTION}

Students who have high mathematical logical intelligence can mention and explain information from questions, can explain the steps for solving problems, can solve problems well and can re-examine the answers. So that subjects who have high mathematical intelligence have no difficulty in working on questions.

In subjects who have medium mathematical logical intelligence, can state the information that is known and asked correctly, can explain the method that will be used to solve the problem and can use their knowledge to solve the problem. However, the subject of mathematical logical intelligence is having difficulty in re-examining the answer.

Subjects who have low mathematical logical intelligence, can explain information that is known from the problem, can explain the steps for solving the problem. However, in its application, the subject of low mathematical logical intelligence has difficulty in solving problems well and has not been able to re-examine the answers.

Based on the results of the study, it is necessary to conduct further research on how difficult students are in solving math problems in a learning context that uses hybrid learning.

\section{REFERENCES}

Abdurrahman, M. (2012). Pendidikan Bagi Anak Berkesulitan Belajar. PT Rineka Cipta.

Abu Shawar, B. A., \& Al-Sadi, J. A. (2010). Learning Management Systems: Are They Knowledge Management Tools? International Journal of Emerging Technologies in Learning (IJET), 5(1), 4. https://doi.org/10.3991/ijet.v5i1.8
87

Aderholt, R. (2020). Coronavirus outbreak shining an even brighter light on internet disparities in rural America. The Hill. https://thehill.com/blogs/congressblog/technology/488848-

coronavirus-outbreak-shining-aneven-brighter-light-on

Alfeld, P. (2004). Understanding Mathematics. Utah: Departemen of Mathematics. University of Utah. http:/www math utah edu/alfeld/math html.

Alqahtani, A. Y., \& Rajkhan, A. A. (2020). E-Learning Critical Success Factors during the COVID-19 Pandemic: A Comprehensive Analysis of ELearning Managerial Perspectives. Education Sciences, 10(9), 216. https://doi.org/10.3390/educsci10 090216

Amelia, Hasanah, P. \& R. (2020). Analisis Keefektifan Pembelajaran Online di Masa Pandemi Covid-19. Maha Guru: Jurnal Pendidikan Guru Sekolah Dasar, 2(1).

Anderson, J. (2020). Should schools close when coronavirus cases are still rare. Yahoo!Finance. https://finance.yahoo.com/news/sc hools-close-coronavirus-casesstill-090027702.html

Azzi-Huck \& Shmis. (2020). Managing the impact of COVID-19 on education systems around the world: How countries are preparing, coping, and planning for recovery. World Bank Blogs. https://blogs.worldbank.org/educa tion/managing-impact-covid-19education-systems-around-worldhow-countries-are-preparing

Blanco, L. J., \& Garrote, M. (2007). 
DOI: https://doi.org/10.24127/ajpm.v10i3.4034

Difficulties in Learning Inequalities in Students of the First Year of Pre-University Education in Spain. EURASIA Journal of Mathematics, Science and Technology Education, 3(3). https://doi.org/10.12973/ejmste/75 401

Bzufka, M. W., Hein, J., \& Neumärker, K. J. (2000). Neuropsychological differentiation of subnormal arithmetic abilities in children. European Child \& Adolescent Psychiatry, 9(S2), S65-S76. https://doi.org/10.1007/s00787007 0010

Cucinotta, D., \& Vanelli, M. (2020). WHO declares COVID-19 a pandemic. Acta Biomedica, 91(1), 157-160.

https://doi.org/10.23750/abm.v91i 1.9397

Dowker, A. (2004). What Works for Children with Mathematical Difficulties? DfES Publications, January 2004, 1-56. www.dfes.go.uk/research

Dwidarti, U., Mampouw, H. L., \& Setyadi, D. (2019). Analisis Kesulitan Siswa dalam Menyelesaikan Soal Cerita pada Materi Himpunan. Jurnal Cendekia: Jurnal Pendidikan Matematika, 3(2), 315-322. https://doi.org/10.31004/cendekia. v3i2.110

Fadhli, M. (2015). PENGEMBANGAN MEDIA PEMBELAJARAN BERBASIS VIDEO KELAS IV SEKOLAH DASAR. Jurnal Dimensi Pendidikan Dan Pembelajaran, 3(1), 24-29. https://doi.org/10.24269/dpp.v3i1. 157

Faizah, F., Sujadi, I., Setiawan, R. (2017). PROSES BERPIKIR SISWA KELAS VII E DALAM
MEMECAHKAN MASALAH MATEMATIKA PADA MATERI PECAHAN DITINJAU DARI KECERDASAN LOGISMATEMATIS Farah. Jurnal Pendidikan Matematika, 1(4), 1525.

Hariani, P. P., \& Wastuti, S. N. Y. (2020). Pemanfaatan E-Learning Pada Pembelajaran Jarak Jauh di Masa Pandemi Covid-19. Biblio Couns: Jurnal Kajian Konseling Dan Pendidikan, 3(1), 41-49. https://doi.org/10.30596/bibliocou ns.v3i2.4656

Hasan, B. (2020). PEMANFAATAN GOOGLE CLASSROOM DALAM MATA KULIAH MENGGUNAKAN MEDIA VIDEO SCREENCAST OMATIC. Widya Wacana: Jurnal Ilmiah, 15(1). https://doi.org/10.33061/j.w.waca na.v15i1.3484

Horn, M. B. (2020). COVID-19's longterm impacts on education in 2020 and beyond. EdSurge. https://www.edsurge.com/news/2 020-03-23-covid-19-s-long-termimpacts-on-education-in-2020and-beyond

Huang, C., Wang, Y., Li, X., Ren, L., Zhao, J., Hu, Y., Zhang, L., Fan, G., Xu, J., Gu, X., Cheng, Z., Yu, T., Xia, J., Wei, Y., Wu, W., Xie, X., Yin, W., Li, H., Liu, M., ... Cao, B. (2020). Clinical features of patients infected with 2019 novel coronavirus in Wuhan, China. The Lancet, 395(10223), 497-506.

https://doi.org/10.1016/S01406736(20)30183-5

Huda, N., \& Kencana, A. G. (2013). Analisis kesulitan siswa berdasarkan kemampuan pemahaman dalam menyelesaikan 
soal cerita pada materi kubus dan balok di kelas VIII SMP Negeri 30 Muaro Jambi. Prosiding Semirata 2013.

Irfan, M., Kusumaningrum, B., Yulia, Y., \& Widodo, S. A. (2020). CHALLENGES DURING THE PANDEMIC: USE OF ELEARNING IN MATHEMATICS LEARNING IN HIGHER EDUCATION. Infinity Journal, 9(2), 147. https://doi.org/10.22460/infinity.v 9i2.p147-158

Karp, P., \& McGowan, M. (2020, March 22). "Clear as mud" schools ask for online learning help as coronavirus policy confusion persists Australia news. The Guardian. https://www.theguardian.com/aust ralia-news/2020/mar/24/clear-asmud-schools-ask-for-onlinelearning-help-as-coronaviruspolicy-confusion-persists

Kelanang, J. G. P., \& \& Zakaria, E. (2012). Mathematics difficulties among primary school students. Advances in Natural and Applied Sciences, 6(7), 1086-1092.

Kobandaha, P. E., \& Fuad, Y. (2019). Algebraic reasoning of students with logical-mathematical intelligence and visual-spatial intelligence in solving algebraic problems. International Journal of Trends in Mathematics Education Research, 2(4), 207211.

https://doi.org/10.33122/ijtmer.v2i 4.138

Krisdiana, I., Murtafiah, W., Masfingatin, T., Setyansyah, R. K., \& Susanti, V. D. (2021). Analysis of Learning Quality through Video-Based eLMA Learning in Department
Mathematics of Education.

Numerical: Jurnal Matematika Dan Pendidikan Matematika, 2332.

Lin, Q., Zhao, S., Gao, D., Lou, Y., Yang, S., Musa, S. S., Wang, M. H., Cai, Y., Wang, W., Yang, L., \& He, D. (2020). A conceptual model for the coronavirus disease 2019 (COVID-19) outbreak in Wuhan, China with individual reaction and governmental action. International Journal of Infectious Diseases, 93, 211-216. https://doi.org/10.1016/j.ijid.2020. 02.058

Lloyd-Sherlock, P. G., Kalache, A., McKee, M., Derbyshire, J., Geffen, L., \& Casas, F. G.-O. (2020). WHO must prioritise the needs of older people in its response to the covid-19 pandemic. $\quad B M J, \quad \mathrm{~m} 1164$. https://doi.org/10.1136/bmj.m116 4

Lwin, M. (2008). How to Multiply Your Child's Intelligence. Penerbit Indeks.

Mahase, E. (2020). Covid-19: WHO declares pandemic because of "alarming levels" of spread, severity, and inaction. $B M J$, m1036. https://doi.org/10.1136/bmj.m103 6

Mujiani, D. S. (2016). PENGARUH MEDIA PEMBELAJARAN DAN KECERDASAN HASIL BELAJAR MATEMATIKA SISWA. JURNAL PENDIDIKAN DASAR, 7(2).

Mukarromah, L. (2019). Kecerdasan Logis Matematis Siswa dalam Menyelesaikan Masalah Matematika Melalui Problem Posing Pada Materi Himpunan Kelas VII MTs Nurul Huda 
DOI: https://doi.org/10.24127/ajpm.v10i3.4034

Mojokerto. Pendidikan Dan

Profesi Pendidik, 14(8), 16-22.

Mustikawati, A. (2020). Analisis Kesalahan Dalam Menyelesaikan Soal Cerita Pembahasan Pola Bilangan Berdasarkan Teori Polya Pada Siswa Kelas VIII Mts Muhammadiah 11 Purbalingga. Universitas Mercu Buana Yogyakarta.

Muthuchamy, I., \& Thiyagu, K. (2011). Technology and teaching: Learning skills. Gyan Publishing House.

OSPI. (2020). Novel coronavirus (COVID-19) in K-12 Sschools: A parent guide. 1-3. https://www.k12.wa.us/sites/defau lt/files/public/communications/C OVID-19 in Schools_Parent Guide.pdf

Rahbarnia, F., Hamedian, S., \& Radmehr, F. (2014). A Study on the relationship between multiple Intelligences and mathematical problem solving based on Revised Bloom Taxonomy. Journal of Interdisciplinary Mathematics, 17(2), 109-134. https://doi.org/10.1080/09720502. 2013.842044

Rosenberg, M. J., \& Foshay, R. (2002). E-learning: Strategies for delivering knowledge in the digital age. Performance Improvement, 41(5), 50-51. https://doi.org/10.1002/pfi.414041 0512

Sastyawati, N. N. S. B. (2012). Pengaruh Model Pembelajaran Penemuan Terbimbing Berbasis LKS terhadap Hasil Belajar Matematika Siswa Ditinjau dari Kecerdasan Logis Matematis pada Siswa Kelas X SMA N 1 Bangli. 2, 1-17.

Setiaji, B., \& Dinata, P. A. C. (2020).
Analisis kesiapan mahasiswa jurusan pendidikan fisika menggunakan e-learning dalam situasi pandemi Covid-19. Jurnal Inovasi Pendidikan IPA, 6(1). https://doi.org/10.21831/jipi.v6i1. 31562

Setiawan, R., Mardapi, D., Pratama, A., \& Ramadan, S. (2019). Efektivitas blended learning dalam inovasi pendidikan era industri 4.0 pada mata kuliah teori tes klasik. Jurnal Inovasi Teknologi Pendidikan, 6(2), 148-158. https://doi.org/10.21831/jitp.v6i2. 27259

Setyoningsih. (2015). E Learning: Pembelajaran Interaktif Berbasis Teknologi. Elementary, 3(1), 3958.

Shereen, M. A., Khan, S., Kazmi, A., Bashir, N., \& Siddique, R. (2020). COVID-19 infection: Emergence, transmission, and characteristics of human coronaviruses. Journal of Advanced Research, 24, 91-98. https://doi.org/10.1016/j.jare.2020 .03 .005

Sholekah, L. M., Anggreini, D., \& Waluyo, A. (2017). Analisis Kesulitan Siswa Dalam Menyelesaikan Soal Matematika Ditinjau Dari Koneksi Matematis Materi Limit Fungsi. WACANA AKADEMIKA: Majalah Ilmiah Kependidikan, 1(2), 151-164. https://doi.org/10.30738/wa.v1i2. 1413

Sohrabi, C., Alsafi, Z., O'Neill, N., Khan, M., Kerwan, A., Al-Jabir, A., Iosifidis, C., \& Agha, R. (2020). World Health Organization declares global emergency: A review of the 2019 novel coronavirus (COVID-19). International Journal of Surgery, 76 , 71-76. 
DOI: https://doi.org/10.24127/ajpm.v10i3.4034

https://doi.org/10.1016/j.ijsu.2020 .02 .034

Sudirman, Cahyono, E., \& Kadir. (2018). Analisis Kemampuan Koneksi Matematis Siswa SMP Pesisir Ditinjau Dari Perbedaan Gender. Jurnal Pembelajaran Berfikir Matematika, 3(2), 11-22. http://ojs.uho.ac.id/index.php/snrk t2017/article/view/3264

Sugiyono. (2012). Metode Penelitian Pendidikan Pendekatan Kuantitatif, Kualitatif dan $R \& D$. Alfabeta.

Suharsimi, A. (2012). Dasar-dasar Evaluasi Pendidikan. Bumi Aksara.

Susanti, V. D. (2018). Analisis Kemampuan Kognitif dalam Pemecahan Masalah Berdasarkan Kecerdasan Logis - Matematis. Jurnal Matematika Dan Pendidikan Matematika, 3(1), 7183.

Ulya, H. (2015). Hubungan Gaya Kognitif dengan Kemampuan Pemecahan Masalah Matematika Siswa. Jurnal Konseling GUSJIGANG, 1(2), 2011-2036.

UNESCO. (2020). Motivating learners during remote learning due to COVID-19 - Tips for teachers. UNESCO.

https://hivhealthclearinghouse.une sco.org/library/documents/motivat ing-learners-during-remotelearning-due-covid-19-tipsteachers

US Department of Health and Enviromental Control. (2019). Higher Education Guidance on Novel Coronavirus or Guidance for IHE that do not have COVID19 identified in their community. 2019.

Wahyono, P., Husamah, H., \& Budi, A. S. (2020). Guru profesional di masa pandemi COVID-19: Review implementasi, tantangan, dan solusi pembelajaran daring. Jurnal Pendidikan Profesi Guru, l(1), 51-65. http://ejournal.umm.ac.id/index.p hp/jppg/article/view/12462

Watkins, J. (2020). Preventing a covid19 pandemic. BMJ, m810. https://doi.org/10.1136/bmj.m810

Willis, J. K., \& Johnson, A. (2001). with MI : to Master Multiplication. Teaching Children Mathematics (TCM), 7(5), 260269. https://doi.org/10.5951/TCM.7.5.0 260

Worldometers. (2020). COVID-19 coronavirus pandemic. Coronavirus. Worldometers. https://www.worldometers.info/co ronavirus/

Yaumi. (2012). Pembelajaran Berbasis Multiple Intelligences. Dian Rakyat.

Zhang, J., Dong, X., Cao, Y., Yuan, Y., Yang, Y., Yan, Y., Akdis, C. A., \& Gao, Y. (2020). Clinical characteristics of 140 patients infected with SARS- CoV- 2 in Wuhan, China. Allergy, 75(7), 1730-1741. https://doi.org/10.1111/all.14238 